\title{
Levels and drivers of fishers' compliance with marine protected areas
}

\author{
$\underline{\text { Adrian Arias }}^{1}, \underline{\text { Joshua E. Cinner }}^{1}, \underline{\text { Rhondda E. Jones }}^{2,3}{\text { and } \text { Robert L. Pressey }^{1}}^{1}$
}

\begin{abstract}
Effective conservation depends largely on people's compliance with regulations. We investigate compliance through the lens of fishers' compliance with marine protected areas (MPAs). MPAs are widely used tools for marine conservation and fisheries management. Studies show that compliance alone is a strong predictor of fish biomass within MPAs. Hence, fishers' compliance is critical for MPA effectiveness. However, there are few empirical studies showing what factors influence fishers' compliance with MPAs. Without such information, conservation planners and managers have limited opportunities to provide effective interventions. By studying 12 MPAs in a developing country (Costa Rica), we demonstrate the role that different variables have on fishers' compliance with MPAs. Particularly, we found that compliance levels perceived by resource users were higher in MPAs (1) with multiple livelihoods, (2) where government efforts against illegal fishing were effective, (3) where fishing was allowed but regulated, (4) where people were more involved in decisions, and (5) that were smaller. We also provide a novel and practical measure of compliance: a compound variable formed by the number illegal fishers and their illegal fishing effort. Our study underlines the centrality of people's behavior in nature conservation and the importance of grounding decision making on the social and institutional realities of each location.
\end{abstract}

Key Words: Costa Rica; illegal fishing; livelihoods; marine reserve; poaching; poverty

\section{INTRODUCTION}

Nature conservation is fundamentally about managing people. Consequently, the effectiveness of conservation interventions depends on people's compliance with regulations. However, noncompliance with environmental regulations is pervasive, as illustrated by the following examples. In the worldwide timber trade, roughly $20 \%$ to $50 \%$ of all timber is of illegal origin (INTERPOL and The World Bank 2010). Meanwhile, in the world's industrial fisheries, estimates of nearly $20 \%$ of reported catch being illegal are probably conservative (Agnew et al. 2009). At least 23,000 elephants were poached in 2013, with wideranging consequences including the decimation of elephant populations, large-scale corruption, and funding of militias (Vira and Ewing 2014). Poaching has ultimately militarized the struggle between poachers and rangers with deadly consequences: more than half of the world's ranger deaths can be attributed to poachers (IUCN 2014). Noncompliance with environmental regulations threatens not only the environment, but also social and economic prosperity.

Compliance with fisheries regulations has been recognized as a vital topic to be addressed to achieve marine conservation goals. Therefore, in this study, we consider compliance though the lens of illegal fishing in marine protected areas (MPAs), which are increasingly used for conservation and fisheries management. International commitments to marine conservation aim to effectively conserve $10 \%$ of the world's coastal and marine areas (CBD 2010), although Devillers et al. (2015) and others have criticized broadly based percentage targets. Regardless of extent and location, however, the effectiveness of MPAs relies largely on users' compliance, particularly that of fishers, because fishing can profoundly degrade global marine ecosystems and biodiversity (Pauly et al. 2002). The mere presence of an MPA does not guarantee fishers' compliance, and its effectiveness can be eroded by illegal fishing. Indeed, ecological performance of MPAs has been clearly linked to compliance (Pollnac et al. 2010, Bergseth et al. 2013).
Despite the crucial importance of compliance for effective MPA management, little empirical research has attempted to investigate compliance with MPAs. Studies in other contexts have examined compliance, for example in hunting (Muth and Bowe 1998, Lindsey et al. 2013) and fisheries (Raakjær et al. 2003, King and Sutinen 2010, Sundström 2012). Although these studies provide useful information that could be applied to MPAs, their transferability is limited because of the different contexts. Further, although some studies have focused on measuring or understanding fishers' compliance in MPAs (Wood 2004, Peterson and Stead 2011, Read et al. 2011, Arias and Sutton 2013, Arias et al. 2014), the current literature and evidence base on compliance levels and, importantly, the factors that influence fishers' compliance with MPAs remain limited (Peterson and Stead 2011, Bergseth et al. 2013). The theoretical concepts underpinning compliance have been recently reviewed in the broader context of nature conservation (Arias 2015), but compliance with MPAs is linked to complex social and institutional interactions (e.g., rules, socio-demographics, and enforcement) that are context dependent.

Illegal fishing, either inside or outside MPAs, is a very broad topic, encompassing, for example, gear types, target species, regulations, and socioeconomic characteristics of regions where illegal fishing takes place (Arias 2015). This heterogeneity implies that we should not expect to find simple, generalizable solutions to noncompliance. Successful management interventions are typically characterized by responses that are adequate for the local socioeconomic and institutional realities (Waylen et al. 2010). It can be expected, therefore, that global progress in minimizing illegal fishing can be achieved through the multiplication of welldesigned and locally relevant interventions that consider contextual factors (Petrossian 2015). Compliance management should be informed by a thorough understanding of factors that influence compliance in specific settings. Managers can then foster positive factors (e.g., high perceived legitimacy for institutions) and mitigate negative ones (e.g., weak social barriers against undesired behaviors).

${ }^{1}$ Australian Research Council Centre of Excellence for Coral Reef Studies, James Cook University, ${ }^{2}$ College of Marine and Environmental Sciences, James Cook University, ${ }^{3}$ Australian Institute of Tropical Health and Medicine, James Cook University 
Table 1. Marine protected areas (MPAs) included in the study and key characteristics. Caletas-Arío and Camaronal were considered as one MPA, as explained in the Methods.

\begin{tabular}{|c|c|c|c|c|c|c|}
\hline Managing institution & Coast & Name & Fishing permitted & Year created & Area $\left(\mathrm{km}^{2}\right)$ & $\begin{array}{c}\text { Clear geographic } \\
\text { boundaries }\end{array}$ \\
\hline SINAC & Caribbean & Cahuita & Yes $^{\dagger}$ & 1970 & 233.0 & No \\
\hline SINAC & Pacific & Santa Rosa & No & 1971 & 464.0 & No \\
\hline SINAC & Pacific & Manuel Antonio & No & 1972 & 420.2 & No \\
\hline SINAC & Pacific & Cabo Blanco & No & 1982 & 16.3 & No \\
\hline SINAC & Pacific & Ostional & Yes & 1983 & 80.6 & No \\
\hline SINAC & Caribbean & Gandoca-Manzanillo & Yes & 1985 & 49.8 & No \\
\hline SINAC & Pacific & Marino Ballena & No & 1990 & 52.3 & No \\
\hline SINAC & Pacific & Caletas-Arío & Yes & 2006 & 198.5 & No \\
\hline SINAC & Pacific & Camaronal & Yes & 2009 & 160.3 & No \\
\hline INCOPESCA & Pacific & Palito-Montero & Yes & 2009 & 6.3 & Yes \\
\hline INCOPESCA & Pacific & Golfo Dulce & Yes & 2010 & 750.0 & No \\
\hline INCOPESCA & Pacific & Isla Caballo & Yes & 2012 & 1.3 & No \\
\hline
\end{tabular}

Here, we use MPAs in Costa Rica as a case study to analyze factors influencing fishers' compliance. MPAs in Costa Rica are affected by illegal fishing (Salas et al. 2012), which we define here either as fishing done in MPAs where fishing is not permitted, or breaking fishing regulations where fishing is permitted, e.g., using gillnets where they are not allowed (Table 1). Apart from Cocos Island National Park (Arias et al. 2014), there are no scientific studies focusing on illegal fishing in Costa Rican MPAs. We investigated illegal fishing within 12 MPAs in Costa Rica (Table 1) to answer two research questions. First, what are the levels of fishers' compliance in each MPA? Second, what is influencing fishers' compliance levels? These two questions are key for understanding and managing compliance (Arias 2015). Our broad goal is to help direct and tailor management efforts that increase conservation effectiveness. The methods used here could also be applied to other areas, where our results could help contextualize compliance.

\section{MPAs in Costa Rica}

Costa Rica has 31 MPAs, only 2 of which are offshore. Three MPAs are in the Caribbean and the rest are in the Pacific. All MPAs are managed by the state. The Ministry of Environment manages 23 MPAs through the National System of Conservation Areas (Sistema Nacional de Áreas de Conservación, or SINAC), and the fisheries authority (Instituto Costarricense de Pesca y Acuicultura, or INCOPESCA) manages the remaining 8 MPAs. MPAs managed by SINAC are patrolled by the Coast Guard and SINAC, and MPAs managed by INCOPESCA are patrolled by the Coast Guard. INCOPESCA has no patrolling mandates but can sanction noncompliance administratively. However, INCOPESCA's fisheries management, including sanctioning processes, is weak. For example, audits done by the Comptroller General found that INCOPESCA has not implemented bag and size limits, temporary and spatial closures are not science based, and the fishery database is outdated (CGR 2012, 2014). INCOPESCA's mismanagement has contributed to the impoverished state of fisheries and fishing communities in Costa Rica, sparking multiple calls for intervention and restructuring (Frente por Nuestros Mares 2013, Comisión Presidencial para la Gobernanza Marina 2012).
SINAC's approach has historically been top-down and includes no-take management categories, leading to MPAs that can disenfranchise fishers (Solis et al. 2012). Since the mid-1990s, SINAC opted to establish MPAs that would allow fishing and created new, more permissive management categories in 2008 (Salas et al. 2012). Similarly, in 2008, INCOPESCA created a type of MPA called a "responsible fishing area." Responsible fishing areas aim for fisheries sustainability and involve a bottom-up approach by which fishing communities propose an area and a management plan to INCOPESCA. Compared with traditional top-down approaches, responsible fishing areas have been generally well received by several artisanal fishing communities (Fargier et al. 2014). Recent marine conservation efforts in Costa Rica, both from SINAC and INCOPESCA, aim to involve stakeholders in decision making. However, still lacking is a strong governance system that allows balanced participation and adequate conservation (Comisión Presidencial para la Gobernanza Marina 2012, Solis et al. 2012, Jimenez-Ramón 2015). The country lacks clear policies that integrate sustainable use, conservation, navigation and ports, and safety at sea (Comisión Presidencial para la Gobernanza Marina 2012). The weak legal and governance system can foster noncompliance, for instance through inadequate legislation and enforcement (Arias et al. 2014), or low perceived legitimacy of management institutions (Levi et al. 2012).

\section{METHODS}

\section{Study sites}

We studied 12 coastal MPAs in Costa Rica, which at the time of sampling represented $46 \%$ of Costa Rica's coastal MPAs, each with different characteristics (Table 1 and Appendix 1). MPAs were chosen purposely to provide a varied sample in terms of size, year created, location, and whether fishing was allowed or not. These characteristics have been described in the literature as factors likely influencing compliance with MPAs (Andrade and Rhodes 2012).

Although Table 1 lists 12 MPAs, the Caletas-Arío and Camaronal MPAs were merged in the analyses because of (1) geographic proximity (Appendix 1); (2) lack of clear boundaries (Table 1); 
(3) same regulations and similar size and age (Table 1); and (4) two artisanal fishing communities being located between them, with interviews revealing that fishers from the two communities fished both areas. For analysis purposes we averaged the age and size of these two MPAs.

\section{Questionnaires and key informant interviews}

Data collection was through questionnaires and key informant interviews, from February to April 2014. The survey was designed to collect information to address each research question; Table 2 summarizes the data and their purpose. Questionnaires were mostly quantitative, and respondents were artisanal fishermen and tourism operators, including those involved in sport fishing. These two stakeholder groups were selected because they spend considerable time on the water, giving them a good idea of the reality of each location. The questionnaires were conducted in communities adjacent to MPAs. We selected questionnaire respondents using snowball sampling, and convenience sampling at beaches, fish landing sites, marinas, and tourism companies. Key informant interviews were semistructured and were used to validate the information received from the questionnaires. Key informants included government staff (Coast Guard, INCOPESCA, and SINAC), managers of tour companies, community leaders, leaders of fishing associations, and researchers. Most key informants were contacted by telephone or email to arrange meetings. All interviews were conducted in person and in Spanish by AA, a Costa Rican.

Table 2. Individual and marine protected area (MPA) variables used to explain compliance, with corresponding research question (s) for each variable.

\begin{tabular}{|c|c|c|}
\hline $\begin{array}{l}\text { Level } \\
\text { Variables } \\
\end{array}$ & Metric & $\begin{array}{l}\text { Research } \\
\text { question } \\
\end{array}$ \\
\hline \multicolumn{3}{|l|}{ Individual level } \\
\hline $\begin{array}{l}\text { Number of people who fish } \\
\text { illegally }\end{array}$ & Six-point scale & $1-2$ \\
\hline Frequency of illegal fishing & Six-point scale & $1-2$ \\
\hline $\begin{array}{l}\text { Seen someone fish illegally in } \\
\text { the MPA }\end{array}$ & Yes or no & 1 \\
\hline $\begin{array}{l}\text { Personally know someone who } \\
\text { knowingly fished illegally in the } \\
\text { MPA }\end{array}$ & Yes or no & 1 \\
\hline Involvement in decision making & $\begin{array}{l}\text { Not involved, passively } \\
\text { involved, very involved }\end{array}$ & 2 \\
\hline Support for MPA & Rated from 0 to 100 & 2 \\
\hline $\begin{array}{l}\text { Effectiveness of government } \\
\text { efforts against illegal fishing }\end{array}$ & Rated from 0 to 100 & 2 \\
\hline Fisherman or not & Yes or no & 2 \\
\hline \multicolumn{3}{|l|}{ MPA level } \\
\hline Size & $\mathrm{Km}^{2}$ & 2 \\
\hline Type & Take or no take & 2 \\
\hline Tourism levels & $\begin{array}{l}\text { Number of hotel rooms in } \\
\text { districts adjacent to MPA }\end{array}$ & 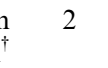 \\
\hline
\end{tabular}

Noncompliance is a sensitive behavior; therefore compliance studies are prone to response and nonresponse bias. Response bias arises when people give inaccurate answers; nonresponse bias occurs when people refuse to participate in surveys. We used several techniques to reduce these biases (see Arias 2015 for a review). First, when approaching potential interviewees, the interviewer identified himself as a student. Students can be considered neutral parties when compared with, for instance, government employees, and respondents can feel more comfortable when talking about sensitive behaviors with a neutral or impartial party (Roggenbuck 1992). Second, potential interviewees were told clearly that the questionnaire was anonymous. Anonymity reduces the "threat" of being accused of noncompliance. Third, the questionnaire started with nonsensitive questions and gradually increased their sensitivity. This allowed respondents to become accustomed to the interviewer and the interviewing process, rather than facing potentially confronting questions at the outset. Fourth, we used indirect questioning. Indirect questioning refers to the compliance behavior of others and not to that of the respondent; we therefore refer to it as "perceived compliance." This technique has been used for several decades and has been shown to reduce bias (e.g., the bias arising from answering in a way that that will be viewed favorably by the interviewer), allowing respondents to mask their own attitudes and behaviors through impersonality (Fisher 1993). Recent compliance studies in conservation contexts indicate the utility of perceived compliance (Arias and Sutton 2013, Cross et al. 2013), coinciding with findings from fields such as marketing (Jo et al. 1997). Additionally, studies have found correlations between perceived compliance and ecological health (Pollnac et al. 2010). Perceived compliance therefore appears to be an adequate proxy for actual compliance. Actual compliance can only be established by direct observation, making it infeasible in most cases. In this study we measured perceived compliance with fishery regulations in MPAs. By using these four techniques, it is likely that we reduced response and nonresponse biases.

\section{Compliance levels}

Our first objective was to identify perceived compliance levels in each MPA. We used a composite measure of perceived compliance based on the number of illegal fishers and the frequency of illegal fishing. Including frequency is key because it provides a measure of illegal fishing effort (Arias 2015, Arias and Sutton 2013). For instance, the impact that five fishers have on an MPA would be very different if they fished every day versus only once a month. Preliminary analysis indicated that the number of illegal fishers and the frequency of illegal fishing were positively correlated $(r$ $(93)=.47, p=0)$; hence, in areas where the number of illegal fishers was low, the frequency of illegal fishing also tended to be low, and vice versa. Because both variables measure compliance and they were moderately correlated, the values for each variable were converted to z-scores and summed to create the composite score for perceived compliance across interviewees for each MPA. $\mathrm{A} z$-score is a score's relationship to the mean in a group of scores, given in standard deviations. Hence, a z-score for an individual MPA can be positive, negative, or zero, indicating whether it is above, below, or equal to, respectively, the MPA population mean. We elicited two additional metrics of perceived compliance by asking participants two proxy questions: (1) if they personally knew somebody who had knowingly fished illegally in the MPA and (2) if they had seen someone fishing illegally in the MPA within the last year. In Australia, Arias and Sutton (2013) found that fishermen who personally knew someone who intentionally fished illegally were more likely to have fished illegally themselves. We performed Mann-Whitney tests to assess if the compliance levels perceived by those who replied yes were different from the levels perceived by those who replied no to each of these two questions. 


\section{Factors influencing compliance}

We used a linear mixed-effect model to quantify the influence on perceived compliance of three MPA- and eight individual-level predictor variables (Table 2 and Appendix 2). We used MPA as a grouping variable (random effect) to account for potential nonindependence of respondents within an MPA. Because there is evidence suggesting that respondents project their own beliefs and evaluations through indirect questioning (Fisher 1993), we hypothesized that individual-level variables (e.g., support of MPA, Table 2) can be related to the compliance levels perceived by respondents. We did not hypothesize or find a theoretical basis for examining interactions between predictor variables. Predictor variables were standardized using $\mathrm{Z}$-scores; this allowed direct evaluation, on the same scale, of their relative effects on perceived compliance levels. The variables included in the model were grouped into three categories: management, planning, and livelihoods (Fig. 1).

Fig. 1. Relationship between marine protected area (MPA) and individual variables and perceived levels of compliance. Circles and triangles represent the estimated effect of each variable. Bars represent 95\% confidence intervals. Positive estimates are shown in green, negative are in red, and no effect is black. Filled red circles indicate a clear negative relationship to compliance; open green circles represent likely positive relationships to compliance ( $\geq 80 \%$ of the confidence intervals in a positive direction).

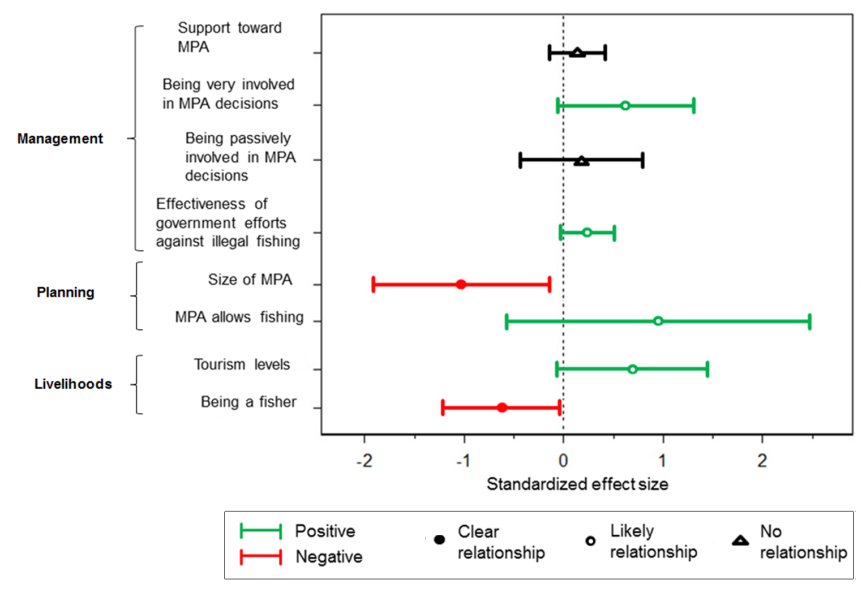

Tourism data were provided by the Costa Rican Tourism Institute in 2015. Data analyses were performed using SPSS version 20 (IBM, Armonk, New York, USA; http://www.ibm.com/) and SPLUS version 8 (TIBCO Software, Palo Alto, California, USA; http://www.tibco.com/). Normality of modeled residuals was analyzed using Q-Q plots.

\section{RESULTS}

We collected a total of 99 questionnaires and 41 key informant interviews (Appendix 3). The response rate was 95\% for the questionnaires and $100 \%$ for key informant interviews. All questionnaire respondents were male, mostly between 30 and 49 years old. Among the respondents, 63 relied exclusively on fishing (hereafter: fishermen), all of whom were associated with Pacific MPAs; 13 relied exclusively on tourism; and 23 had multiple livelihoods including fishing or tourism.
What were the levels of compliance in each MPA?

There was a high variability in perceived compliance levels between MPAs (Fig. 2). Levels of perceived compliance in PalitoMontero, Cahuita, and Gandoca-Manzanillo were above average (Fig. 2). The absolute number of illegal fishers was low to very low in Palito-Montero, Cahuita, and Gandoca-Manzanillo, and medium in all MPAs except for Caballo, where it was high. Illegal fishing occurred nearly every day in all MPAs except PalitoMontero, Cahuita, and Gandoca-Manzanillo. Qualitative key informant interviews did not diverge from the information received from the quantitative questionnaires and helped as validation.

Fig. 2. Mean perceived compliance level per marine protected area (MPA). Numbers on the y-axis indicate mean z-scores per MPA. Z-scores are standard deviations above or below the MPA population mean indicated by zero on the y-axis and representing the mean z-score across MPAs. Error bars indicate standard errors of the mean for each MPA, or variation between responses of interviewees for each MPA.

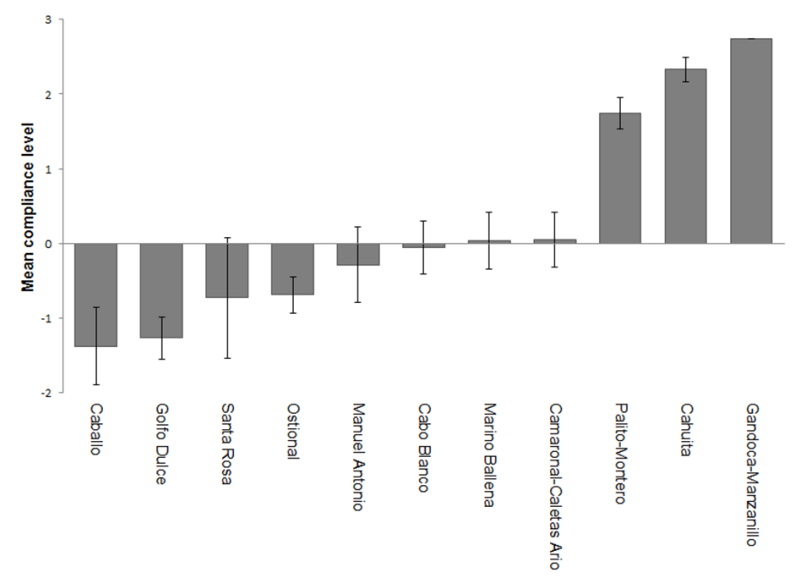

Sixteen percent of respondents said that they had not seen anyone fishing illegally within their corresponding MPA during the last year; $47 \%$ of these respondents were from Palito-Montero, Cahuita, and Gandoca-Manzanillo. Eighty-four percent of respondents mentioned that they had seen someone fishing illegally within the MPA during the last year, and $85 \%$ personally knew someone who intentionally fished illegally within the MPA. The compliance levels perceived by those who reported seeing someone fish illegally within the MPA during the last year were significantly lower than the compliance levels perceived by those who did not $($ mean $=-0.2$ and 1.3, respectively; $\mathrm{U}=299.5, p=$ 0.002). The compliance levels perceived by those who reported personally knowing someone who fished illegally within the MPA were not significantly different from the compliance levels perceived by those who did not $($ mean $=-0.08$ and 0.17 , respectively; $\mathrm{U}=499.5, p=0.44)$.

\section{What was influencing compliance levels?}

\section{Key informants}

The key informant interviews provided important insights into perceived compliance with MPAs. Key informants mentioned that poverty and the lack of livelihood alternatives were serious problems causing some of the illegal fishing. They also reported 
a paucity of resources to patrol and adequately manage the MPAs. For instance, only Santa Rosa had a functioning patrol system operated by the park; the other areas either had no boats or the boats were inoperable (e.g., damaged, lack of funds, no qualified staff to operate them). Key informants mentioned that the Coast Guard had multiple duties and that illegal fishing was not a high priority compared with search and rescue and combatting drug trafficking. Lastly, there was a general belief that artisanal fishermen and government institutions interacted sparsely, and that this lack of communication should be corrected.

\section{Linear mixed-effects model}

The linear mixed-effects model (Fig. 1) revealed two predictor variables that had clear negative relationships with perceived compliance: size of the MPA and being a fisher. Additionally, four other variables indicated a likely positive relationship with perceived compliance: (1) tourism levels, (2) effectiveness of government efforts to combat illegal fishing, (3) MPAs that allowed some fishing, and (4) strong involvement in decision making. Support for MPAs and passive involvement in decision making (e.g., attending meetings but not participating in them) had no discernible relationship with perceived compliance. See Appendix 4 for additional figures.

\section{DISCUSSION}

Illegal fishing is a problem for many MPAs globally (Mora et al. 2006, Pollnac et al. 2010), and we found it present, at varying levels, in all of the MPAs that we assessed. Nearly all respondents had seen illegal fishing occurring inside MPAs and personally knew someone who intentionally fished illegally within an MPA. These responses provide a measure of descriptive social norms, i.e., what others do (Cialdini et al. 1991), suggesting that illegal fishing is common. Only three MPAs, Palito-Montero, Cahuita, and Gandoca-Manzanillo, had markedly high levels of perceived compliance (Fig. 2). Illegal fishing is of concern not only because of its likely negative environmental effects, but also because noncompliance can have a domino effect. If fishers believe that others are fishing illegally and perhaps are catching more fish (Appendix 2, Table A2.1), they are less likely to comply themselves, so compliance levels would continually decline (Cialdini et al. 1991, Arias 2015). For example, a participant from Cabo Blanco stated that most people used to respect the MPA, but government enforcement stopped and some free riders started fishing illegally. Illegal fishing then became so widespread that there was no noticeable difference between fishing inside versus outside of this small MPA.

It is often assumed that MPA compliance is associated solely with enforcement efforts. Enforcement is typically necessary, but not sufficient, to ensure compliance (Arias 2015). We found that government efforts against illegal fishing, normally considered as enforcement, can have a positive effect on perceived compliance; however, other variables were also related to perceived compliance (Fig. 1). Levels of perceived compliance were related to a range of socioeconomic and institutional conditions, some that are reasonably easy to influence and others that are more difficult to influence.

The compliance drivers easiest to influence include those associated with management, i.e., participation, support, and enforcement. Conservation is mostly about managing people, and approaches that are inclusive of stakeholders tend to be more successful than those that exclude stakeholders (Jentoft 2000,
Schultz et al. 2011). A meta-analysis of 55 studies identified participation as a critical factor influencing compliance with protected areas (Andrade and Rhodes 2012). However, our results suggest that only the higher levels of involvement with MPA decisions were positively related to compliance. Simply supporting an MPA, or being weakly involved in decisions, seems insufficient to positively influence compliance (Fig. 1). In fact, some studies mention that participation can have negative outcomes, such as dilution of scientific input and "elite capture," a situation in which only some participate and displace others (Schultz et al. 2011). We did not collect information to further describe the participation processes and therefore cannot determine if some aspects of participation were eroding compliance in our study sites. It has been suggested that elite capture of participation applies in Golfo Dulce (Solis et al. 2012), and this might negatively affect compliance. Management interventions should be adaptive, aiming for high levels of participation that foster positive outcomes such as empowerment, legitimacy, and ultimately, increased compliance. Some of these positive outcomes can also be stimulated earlier through an MPA's planning process.

The compliance drivers associated with planning, such as size of the MPA and whether or not fishing is allowed, can be easy to plan for in advance, but can be difficult to change in existing MPAs, particularly when these changes require adjustments to laws that can take years to come into effect. Planning considerations such as MPA size, spacing, and location can also influence the achievement of ecological objectives (Green et al. 2014). However, there are critical trade-offs in planning between achieving compliance and achieving ecological objectives. Our results suggest that larger MPAs and those that were no-take had lower levels of perceived compliance (Fig. 1). Ecological considerations for planning MPAs commonly suggest that large, no-take MPAs are preferable to smaller ones because they can, for instance, encompass more habitats and highly mobile species, and offer higher levels of protection (Edgar et al. 2014, Green et al. 2014). However, larger MPAs can be harder to manage, and excluding fishing from coastal MPAs in developing countries is likely to create friction with fishing communities (Ban et al. 2011); hence, compliance and resultant ecological health are likely to weaken. Embedded in social-ecological systems in developing countries, smaller MPAs that allow regulated fishing tend to be more tractable. We believe that Costa Rica's moves to include permissive MPA management categories (e.g., responsible fishing areas) and increase stakeholder participation were steps in the right direction. However, further steps are required to significantly strengthen conservation planning, marine governance, and socioeconomic conditions in coastal areas.

We found two compliance drivers related to livelihoods, which are notoriously difficult to change in fishing communities (Hill et al. 2012, Cinner 2014). We found that relying solely on fishing had a clear negative relationship with perceived compliance, and increased levels of tourism had a likely positive relationship with perceived fishers' compliance (Fig. 1). We believe that tourism levels can serve as a proxy for livelihood options, at least in this study's context. Costa Rica has a strong nature-based tourism market; most tourists engage in ecotourism and nautical tourism, such as beach going, snorkeling, diving, and sport fishing (ICT 2015). High levels of tourism can generate more direct and indirect jobs. Protected areas are associated with reduced poverty 
in Costa Rica (Andam et al. 2010), mainly through tourism (Ferraro and Hanauer 2014). Increased tourism can offer a wide diversity of livelihood alternatives, presenting fishermen with options for relying less on catch and hence, for some people, potentially reducing the motivations to fish illegally. Nevertheless, the economic activity around sites with high levels of tourism could also act as an incentive for some fishermen to stay in the fishery or fish more (Daw et al. 2012), e.g., to meet increased local demand for seafood. Therefore, the causal mechanisms through which tourism and associated livelihoods influence fishers' compliance are unclear. Although fishers' compliance with MPAs could potentially improve through more livelihood alternatives, we believe that this can be a challenging strategy that should be approached cautiously, and with objectives other than compliance with MPAs, e.g., poverty alleviation.

We identified steps toward informing and directing interventions to enhance conservation through increased compliance. At the time of sampling, we assessed perceived compliance with fisheries regulations in $\sim 50 \%$ of Costa Rica's coastal MPAs. However, because our selection of MPAs was nonrandom, the ability to draw inferences outside our sample is limited. We provided a novel and improved way of measuring compliance: a compound variable formed by the number of people fishing illegally and a measure of their effort. Future studies could make further advances in two ways. First, more needs to be known about the mechanisms through which factors such as management, planning, and livelihoods influence compliance. Such studies would benefit from small geographical scales and large sample sizes. Second, conducting in-depth research in high-compliance sites would provide insights into key drivers of compliance. High compliance is the target behavior; therefore, areas with markedly high compliance (or "bright spots") can provide useful information on the factors that strengthen fishers' compliance. In the case of MPAs in Costa Rica, Cahuita, Gandoca-Manzanillo, and Palito-Montero seem to be bright spots (Fig. 2).

\section{CONCLUSION}

We found considerable levels of illegal fishing in multiple Costa Rican MPAs. However, there were sites with comparatively high levels of perceived compliance. Our study builds on previous research (Peterson and Stead 2011, Andrade and Rhodes 2012, Karper and Lopes 2014), adding information on the links between compliance, livelihoods, and participation in management of MPAs. However, the mechanisms through which participation and livelihoods affect compliance remain unclear, indicating an important area for future research. Our results suggest that MPA design can play an important role in fishers' compliance (Ban et al. 2011, Arias et al. 2014) and that enforcement is not a requirement for high compliance. Nevertheless, enforcement can help uphold compliance levels, especially in areas where there is a high dependence on fishing (e.g., Palito-Montero). Governments and conservation practitioners have a suite of tools to increase compliance. We identified several of these tools, along with some of the implications of using them. We emphasize, however, that adequate compliance interventions must be tailored to their particular contexts: There are no blanket solutions.

Responses to this article can be read online at: http://www.ecologyandsociety.org/issues/responses. $\mathrm{php} / 7999$

\section{Acknowledgments:}

Thanks to all the people who participated in this study. We thank Jorge Álvarez-Romero, Brock Bergseth, Alastair Birtles, Georgina Gurney, Cindy Huchery, Aaron MacNeil, and participants of the University of Exeter-CSIRO-James Cook University Workshop in Townsville. We would also like to thank the useful comments provided by the editors and anonymous reviewers. We acknowledge support from the PADI Foundation and the Australian Research Council. AA thanks the Australian people for support through AusAID. This study was approved by the James Cook University human ethics committee.

\section{LITERATURE CITED}

Agnew, D. J., J. Pearce, G. Pramod, T. Peatman, R. Watson, J. R. Beddington, and T. J. Pitcher. 2009. Estimating the worldwide extent of illegal fishing. PLoS ONE 4(2):e4570. http://dx.doi. org/10.1371/journal.pone.0004570

Andam, K. S., P. J. Ferraro, K. R. E. Sims, A. Healy, and M. B. Holland. 2010. Protected areas reduced poverty in Costa Rica and Thailand. Proceedings of the National Academy of Sciences of the United States of America 107:9996-10001. http://dx.doi. org/10.1073/pnas.0914177107

Andrade, G. S. M., and J. R. Rhodes. 2012. Protected areas and local communities: an inevitable partnership toward successful conservation strategies? Ecology and Society 17(4):14. http://dx. doi.org/10.5751/ES-05216-170414

Arias, A. 2015. Understanding and managing compliance in the nature conservation context. Journal of Environmental Management 153:134-143. http://dx.doi.org/10.1016/j. jenvman.2015.02.013

Arias, A., R. L. Pressey, R. E. Jones, J. G. Álvarez-Romero, and J. E. Cinner. 2014. Optimizing enforcement and compliance in offshore marine protected areas: a case study from Cocos Island, Costa Rica. Oryx. Available on CJO2014. http://dx.doi. org/10.1017/S0030605314000337

Arias, A., and S. G. Sutton. 2013. Understanding recreational fishers' compliance with no-take zones in the Great Barrier Reef Marine Park. Ecology and Society 18(4):18. http://dx.doi. org/10.5751/ES-05872-180418

Ban, N. C., V. M. Adams, G. R. Almany, S. Ban, J. E. Cinner, L. J. McCook, M. Mills, R. L. Pressey, and A. White. 2011. Designing, implementing and managing marine protected areas: emerging trends and opportunities for coral reef nations. Journal of Experimental Marine Biology and Ecology 408:21-31. http:// dx.doi.org/10.1016/j.jembe.2011.07.023

Bergseth, B. J., G. R. Russ, and J. E. Cinner. 2013. Measuring and monitoring compliance in no-take marine reserves. Fish and Fisheries 16:240-258. http://dx.doi.org/10.1111/faf.12051

Cialdini, R. B., C. A. Kallgren, and R. R. Reno. 1991. A focus theory of normative conduct: a theoretical refinement and reevaluation of the role of norms in human behavior. Pages 201-234 in M. P. Zanna, editor. Advances in experimental social psychology. Volume 24. Academic Press, San Diego, California, USA. http://dx.doi.org/10.1016/s0065-2601(08)60330-5 
Cinner, J. 2014. Coral reef livelihoods. Current Opinion in Environmental Sustainability 7:65-71. http://dx.doi.org/10.1016/j. cosust.2013.11.025

Comisión Presidencial para la Gobernanza Marina. 2012. Informe. Presidencia República de Costa Rica, San José, Costa Rica.

Contraloría General de la Repúblic (CGR). 2012.Informe sobre auditoría de carácter especial efectuada en el Instituto Costarricense de Pesca y Acuicultura (INCOPESCA) relacionado con el cumplimiento de sus funciones en materia de conservación del recurso marino. CGR, San José, Costa Rica.

Contraloría General de la Repúblic (CGR) 2014. Auditoría de carácter especial sobre la gestión del Instituto Costarricense de Pesca y Acuiclutura (INCOPESCA) vinculada al cumplimiento de sus funciones en materia de aprovechamiento y uso de sostenible de los recursos marinos. CGR, San José, Costa Rica.

Convention on Biological Diversity (CBD). 2010. Decision X2. Strategic Plan for Biodiversity 2011-2020 and the Aichibiodiversity targets. Tenth Meeting of the Conference of the Parties to the Convention on Biological Diversity. United Nations Environment Programme, Nagoya, Japan.

Cross, P., F. A. V. St. John, S. Khan, and A. Petroczi. 2013. Innovative techniques for estimating illegal activities in a humanwildlife-management conflict. PLOS ONE 8:e53681. http://dx. doi.org/10.1371/journal.pone.0053681

Daw, T. M., J. E. Cinner, T. R. McClanahan, K. Brown, S. M. Stead, N. A. J. Graham, and J. Maina. 2012. To fish or not to fish: factors at multiple scales affecting artisanal fishers' readiness to exit a declining fishery. $P \operatorname{LOS} O N E$ 7:e31460. http://dx.doi. org/10.1371/journal.pone.0031460

Devillers, R., R. L. Pressey, A. Grech, J. N. Kittinger, G. J. Edgar, T. Ward, and R. Watson. 2015. Reinventing residual reserves in the sea: are we favouring ease of establishment over need for protection? Aquatic Conservation 25:480-504. http://dx.doi. org/10.1002/aqc. 2445

Edgar, G. J., R. D. Stuart-Smith, T. J. Willis, S. Kininmonth, S. C. Baker, S. Banks, N. S. Barrett, M. A. Becerro, A. T. F. Bernard, J. Berkhout, C. D. Buxton, S. J. Campbell, A. T. Cooper, M. Davey, S. C. Edgar, G. Försterra, D. E. Galván, A. J. Irigoyen, D. J. Kushner, R. Moura, P. E. Parnell, N. T. Shears, G. Soler, E. M. A. Strain, and R. J. Thomson. 2014. Global conservation outcomes depend on marine protected areas with five key features. Nature 506:216-220. http://dx.doi.org/10.1038/nature13022

Fargier, L., H. J. Hartmann, and H. Molina-Ureña. 2014. "Marine areas of responsible fishing": a path toward small-scale fisheries co-management in Costa Rica? Perspectives from Golfo Dulce. Pages 155-179 in F. Amezcua and B. Bellgraph, editors. Fisheries management of Mexican and Central American estuaries. Springer, Dordrecht, Netherlands. http://dx.doi. org/10.1007/978-94-017-8917-2_10

Ferraro, P. J., and M. M. Hanauer. 2014. Quantifying causal mechanisms to determine how protected areas affect poverty through changes in ecosystem services and infrastructure. Proceedings of the National Academy of Sciences of the United States of America 111:4332-4337. http://dx.doi.org/10.1073/ pnas. 1307712111
Fisher, R. J. 1993. Social desirability bias and the validity of indirect questioning. Journal of Consumer Research 20:303-315.

Frente por Nuestros Mares. 2013. Petición reforma Ley de Creación de INCOPESCA. San José, Costa Rica.

Green, A. L., A. P. Maypa, G. R. Almany, K. L. Rhodes, R. Weeks, R. A. Abesamis, M. G. Gleason, P. J. Mumby, and A. T. White. 2014. Larval dispersal and movement patterns of coral reef fishes, and implications for marine reserve network design. Biological Reviews. 90:1215-1247. http://dx.doi.org/10.1111/brv.12155

Hill, N. A. O., J. M. Rowcliffe, H. J. Koldewey, and E. J. MilnerGulland. 2012. The interaction between seaweed farming as an alternative occupation and fisher numbers in the Central Philippines. Conservation Biology 26:324-334. http://dx.doi. org/10.1111/j.1523-1739.2011.01796.x

Instituto Costarricense de Turismo (ICT). 2015. Actividades realizadas por turistas 2009-2013. ICT, San José, Costa Rica. [online] URL: http://www.visitcostarica.com/ict/pdf/ estadisticas/3-3_Actividades_Realizadas_VIA_AEREA_2009-2013. pdf

INTERPOL and The World Bank. 2010. Chainsaw project: an INTERPOL perspective on law enforcement in illegal logging. INTERPOL and The World Bank, Washington, D.C., USA, and Lyon, France.

International Union for Conservation of Nature (IUCN). 2014. Rising murder toll of park rangers calls for tougher laws. IUCN, Gland, Switzerland. [online] URL: http://www.iucn.org/?17196/ Rising-murder-toll-of-park-rangers-calls-for-tougher-laws

Jentoft, S. 2000. Legitimacy and disappointment in fisheries management. Marine Policy 24:141-148. http://dx.doi.org/10.1016/ $\underline{\text { S0308-597X(99)00025-1 }}$

Jimenez-Ramón, J. A. 2015. Urge una agenda marina en Costa Rica. La Nación, San José, Costa Rica.

Jo, M.-S., J. Nelson, and P. Kiecker. 1997. A model for controlling social desirability bias by direct and indirect questioning. Marketing Letters 8:429-437. http://dx.doi.org/10.1023/A:1007951313872

Karper, M. A. M., and P. F. M. Lopes. 2014. Punishment and compliance: exploring scenarios to improve the legitimacy of small-scale fisheries management rules on the Brazilian coast. Marine Policy 44:457-464. http://dx.doi.org/10.1016/j.marpol.2013.10.012

King, D. M., and J. G. Sutinen. 2010. Rational noncompliance and the liquidation of Northeast groundfish resources. Marine Policy 34:7-21. http://dx.doi.org/10.1016/i.marpol.2009.04.023

Levi, M., T. R. Tyler, and A. Sacks. 2012. The reasons for compliance with the law. Pages 70-93 in R. Goodman, D. Jinks, and A. K. Woods, editors. Understanding social action, promoting human rights. Oxford University Press, New York, New York, USA. http://dx.doi.org/10.1093/acprof:oso/9780195371895.003.0004

Lindsey, P. A., G. Balme, M. Becker, C. Begg, C. Bento, C. Bocchino, A. Dickman, R. W. Diggle, H. Eves, P. Henschel, D. Lewis, K. Marnewick, J. Mattheus, J. Weldon McNutt, R. McRobb, N. Midlane, J. Milanzi, R. Morley, M. Murphree, V. Opyene, J. Phadima, G. Purchase, D. Rentsch, C. Roche, J. Shaw, H. van der Westhuizen, N. van Vliet, and P. Zisadza-Gandiwa. 2013. The bushmeat trade in African savannas: impacts, drivers, and possible solutions. Biological Conservation 160:80-96. http:// dx.doi.org/10.1016/j.biocon.2012.12.020 
Mora, C., S. Andrèfouët, M. J. Costello, C. Kranenburg, A. Rollo, J. Veron, K. J. Gaston, and R. A. Myers. 2006. Coral reefs and the global network of marine protected areas. Science 312:1750-1751. http://dx.doi.org/10.1126/science.1125295

Muth, R. M., and J. F. Bowe, Jr. 1998. Illegal harvest of renewable natural resources in North America: toward a typology of the motivations for poaching. Society \& Natural Resources 11:9-24. http://dx.doi.org/10.1080/08941929809381058

Pauly, D., V. Christensen, S. Guénette, T. J. Pitcher, U. R. Sumaila, C. J. Walters, R. Watson, and D. Zeller. 2002. Towards sustainability in world fisheries. Nature 418:689-695. http://dx. doi.org/10.1038/nature01017

Peterson, A. M., and S. M. Stead. 2011. Rule breaking and livelihood options in marine protected areas. Environmental Conservation 38:342-352 http://dx.doi.org/10.1017/S0376892911000178

Petrossian, G. A. 2015. Preventing illegal, unreported and unregulated (IUU) fishing: a situational approach. Biological Conservation 189:39-48. http://dx.doi.org/10.1016/j.biocon.2014.09.005

Pollnac, R., P. Christie, J. E. Cinner, T. Dalton, T. M. Daw, G. E. Forrester, N. A. J. Graham, and T. R. McClanahan. 2010. Marine reserves as linked social-ecological systems. Proceedings of the National Academy of Sciences of the United States of America 107:18262-18265. http://dx.doi.org/10.1073/pnas.0908266107

Raakjær Nielsen, J., and C. Mathiesen. 2003. Important factors influencing rule compliance in fisheries lessons from Denmark. Marine Policy 27:409-416. http://dx.doi.org/10.1016/S0308-597X (03)00024-1

Read, A. D., R. J. West, M. Haste, and A. Jordan. 2011. Optimizing voluntary compliance in marine protected areas: a comparison of recreational fisher and enforcement officer perspectives using multi-criteria analysis. Journal of Environmental Management 92:2558-2567. http://dx.doi.org/10.1016/j. jenvman.2011.05.022

Roggenbuck, J. W. 1992. Use of persuasion to reduce resource impacts and visitor conflicts. Pages 149-208 in M. J. Manfredo, editor. Influencing human behavior: theory and application in recreation, tourism, and natural resources management. Sagamore, Champaign, Illinois, USA.

Salas, E., E. Ross-Salazar, and A. Arias. 2012. Diagnóstico de áreas marinas protegidas y áreas marinas para la pesca responsable en el Pacífico costarricense. Fundación MarViva, San José, Costa Rica.

Schultz, L., A. Duit, and C. Folke. 2011. Participation, adaptive co-management, and management performance in the world network of biosphere reserves. World Development 39:662-671. http://dx.doi.org/10.1016/j.worlddev.2010.09.014

Solis, V., M. Fonseca-Borrás, and D. Barguil-Gallardo. 2012. Estudio regional sobre las dimensiones sociales en el manejo de áreas Marinas Protegidas: casos en Costa Rica, Nicaragua, Honduras y Panamá. International Collective in Support of Fishworkers, Chennai, India.

Sundström, A. 2012. Corruption and regulatory compliance: experimental findings from South African small-scale fisheries. Marine Policy 36:1255-1264. http://dx.doi.org/10.1016/j. marpol.2012.03.013
Vira, V., and T. Ewing. 2014. Ivory's curse: the militarization and professionalization of poaching in Africa. Born Free USA and C4ADS, Washington, D.C, USA.

Waylen, K. A., A. Fischer, P. J. K. McGowan, S. J. Thirgood and E. J. Milner-Gulland. 2010. Effect of local cultural context on the success of community-based conservation interventions. Conservation Biology 24:1119-1129. http://dx.doi.org/10.1111/ j.1523-1739.2010.01446.X

Wood, L. J. 2004. Motives for poaching in marine protected areas in the Seychelles. Western Indian Ocean Journal of Marine Science 3:199-208. 
Appendix 1. Interactive map of study sites - Requires Google Earth to open

Please click here to download file 'appendix1. $\mathrm{kmz}$ '. 
Appendix 2. Additional methods, results, and discussion.

\section{METHODS}

MPAs were either long-established (24-35 years) or recent (less than 10 years). All recent MPAs allowed fishing (Table 1), so the effect of age group on compliance levels could only be tested in MPAs that allowed fishing, and preliminary analysis revealed no effect. Hence MPA age (Table 1) was excluded from the linear mixed-effect model.

To obtain additional information on factors influencing compliance we asked participants what they thought was driving compliance and noncompliance, ranking these responses according to the number of mentions.

\section{RESULTS}

Table A2.1 summarizes the salient factors that respondents thought influenced compliance (i.e., why fishermen follow MPA rules) and noncompliance (i.e., why fishermen break MPA rules).

Table A2.1. Three highest-ranked factors considered by respondents to influence compliance and noncompliance. $\mathrm{n}=$ number of mentions by respondents.

\begin{tabular}{cll}
\hline \hline Rank & \multicolumn{1}{c}{ Compliance } & \multicolumn{1}{c}{ Noncompliance } \\
\hline 1 & Afraid of sanctions $(\mathrm{n}=57)$ & $\begin{array}{l}\text { Better/easier fishing in protected area } \\
(\mathrm{n}=49)\end{array}$ \\
2 & $\begin{array}{l}\text { Complying brings benefits (individual, } \\
\text { communal, or environmental) }(\mathrm{n}=52)\end{array}$ & Financial hardship $(\mathrm{n}=23)$ \\
3 & Complying is the right thing to do $(\mathrm{n}=16)$ & Unlikely to get sanctioned $(\mathrm{n}=21)$ \\
\hline
\end{tabular}

\section{DISCUSSION}

The factors influencing compliance that were identified by respondents revealed that there is some degree of purposeful, voluntary compliance (Table A2.1). Voluntary compliance is preferable to coerced compliance because it can: 1) indicate that natural resource users are assertive about the benefits of regulating use of natural resources, 2) provide a buffer when costly enforcement is suspended, and 3) confirm effective governance and management (Arias, 2015). Some respondents believed that compliance involves environmental, personal, or communal benefits (Table A2.1). The fact that most respondents believed that fishing illegally in MPAs could be better or easier than fishing outside of them (Table A2.1), suggests that MPAs, despite varying amounts of illegal fishing, could contain higher fish biomass than the non-protected areas. Even though voluntary compliance is preferred, a degree of enforcement is typically necessary (Arias, 2015; Braithwaite \& Braithwaite, 2001; Tyler, 2003) to maintain deterrence and compliance (Table A2.1). We therefore consider that if the deficit of enforcement efforts detected in most of these sites were to continue, or deteriorate further, fishers who might be complying voluntarily could defect in the face of flagrant noncompliance. This is supported by our results, which suggest 
that effective government efforts to combat illegal fishing can relate positively to perceived compliance (Figure 1). Furthermore, patrol efforts (either formal or informal) tend to be more effective in smaller areas (Ban et al., 2011), and this might explain why perceived compliance was lower in larger MPAs (Figure 1).

We were also interested in knowing what respondents thought was influencing noncompliance. Respondents cited poverty and better fishing in MPAs as the main reasons for noncompliance (Table A2.1). Coastal communities in Costa Rica are predominantly poor (Morales-Aguilar, 2013). Scarcity of food or income could induce some people to fish illegally in MPAs, mostly if they believe that there are more fish in them than outside (Table A2.1). It is worth noting that, in Cahuita and Gandoca-Manzanillo, both in the Caribbean, people do not rely entirely on fishing, and fishing in Costa Rica's Caribbean is much less productive than the Pacific (FAO, 2011). This low dependence on fishing can help explain the higher compliance in these two Caribbean sites. In contrast, the communities adjacent to MPAs with low perceived compliance (e.g., Caballo, Golfo Dulce, and Santa Rosa) rely substantially on fishing (Marín-Cabrera, 2012; Solis et al., 2012). This is particularly true at the small island of Caballo, where fishing is the only livelihood. These facts support the results of our model, which shows that fishers perceive lower levels of compliance than nonfishers (Figure 1). It is likely that compliance levels were negatively affected by a high dependence on declining fisheries, and a lack of livelihood options. Similar conclusions have been drawn by previous studies. Peterson and Stead (2011) suggested that the main causes for noncompliance with MPAs in Rodriguez, an island in the Western Indian Ocean, were lack of food and limited livelihood opportunities. Similarly, Karper and Lopes (2014) found that artisanal fishermen that depended more on fisheries had stronger intentions to break rules in a Brazilian MPA. Thus, declining or collapsed fisheries can give rise to illegal fishing and other types of noncompliance, and a high dependence on fisheries exacerbates the problem (Brashares et al., 2014; Gettleman, 2015). 


\section{LITERATURE CITED}

Arias, A. (2015). Understanding and managing compliance in the nature conservation context. Journal of Environmental Management, 153, 134-143. doi: http://dx.doi.org/10.1016/i.jenvman.2015.02.013

Ban, N. C., Adams, V. M., Almany, G. R., Ban, S., Cinner, J. E., McCook, L. J., . . White, A. (2011). Designing, implementing and managing marine protected areas: Emerging trends and opportunities for coral reef nations. Journal of Experimental Marine Biology and Ecology, 408(1-2), 21-31. doi: http://dx.doi.org/10.1016/i.jembe.2011.07.023

Braithwaite, V., \& Braithwaite, J. (2001). An evolving compliance model for tax enforcement. In N. Shover \& J. P. Wright (Eds.), Crimes of Privilege (pp. 405-419). New York: Oxford University Press.

Brashares, J. S., Abrahms, B., Fiorella, K. J., Golden, C. D., Hojnowski, C. E., Marsh, R. A., . . Withey, L. (2014). Wildlife decline and social conflict. Science, 345(6195), 376-378. doi: http://dx.doi.org/10.1126/science.1256734

FAO. (2011). Coastal fisheries of Latin America and the Caribbean. In S. Salas, R. Chuenpagdee, A. Charles \& J. C. Seijo (Eds.), FAO fisheries and aquaculture techincal paper (pp. 444). Rome: FAO.

Gettleman, J. (2015, 24/01/2015). Meant to keep malaria out, mosquito nets are used to haul fish in, New York Times. Retrieved from http://www.nytimes.com/2015/01/25/world/africa/mosquito-nets-for-malaria-spawn-newepidemic-overfishing.html?ref=science

Karper, M. A. M., \& Lopes, P. F. M. (2014). Punishment and compliance: Exploring scenarios to improve the legitimacy of small-scale fisheries management rules on the Brazilian coast. Marine Policy, 44(0), 457-464. doi: http://dx.doi.org/10.1016/i.marpol.2013.10.012

Marín-Cabrera, M. (2012). Identificación y caracterización de actores institucionales y de la sociedad civil claves en la gestión de las AMUM Golfo de Nicoya y Pacífico Sur.

Proyecto SINAC-BID-MarViva, Manejo integrado de los recursos marino costeros en la Provincia de Puntarenas. San José, Costa Rica.

Morales-Aguilar, N. (2013). Estado de la Nación en desarrollo humano sostenible: Aspectos relevantes en desigualdad y pobreza al 2012. San José, Costa Rica: Retrieved from http://estadonacion.or.cr/files/biblioteca virtual/019/morales 2013.pdf.

Peterson, A. M., \& Stead, S. M. (2011). Rule breaking and livelihood options in marine protected areas. Environmental Conservation, 38(3), 342-352 doi: http://dx.doi.org/10.1017/S0376892911000178

Solis, V., Fonseca-Borrás, M., \& Barguil-Gallardo, D. (2012). Estudio Regional sobre las Dimensiones Sociales en el Manejo de Áreas Marinas Protegidas: Casos en Costa Rica, Nicaragua, Honduras y Panamá. In CoopeSoliDar (Ed.), (pp. 163).

Tyler, T. R. (2003). Procedural Justice, Legitimacy, and the Effective Rule of Law. Crime and Justice, 30, 283-357. 
Appendix 3. Number of questionnaires and key informant interviews per MPA.

\begin{tabular}{lccc}
\hline Marine Protected Area & Questionnaires & Key informant interviews & Total \\
\hline Santa Rosa & 5 & 9 & 14 \\
Ostional & 11 & 4 & 15 \\
Camaronal-Caletas Arío & 9 & 3 & 12 \\
Cabo Blanco & 11 & 2 & 13 \\
Palito-Montero & 11 & 2 & 13 \\
Caballo & 8 & 1 & 9 \\
Manuel Antonio & 9 & 5 & 14 \\
Marino Ballena & 9 & 5 & 14 \\
Golfo Dulce & 16 & 5 & 21 \\
Cahuita & 7 & 3 & 10 \\
Gandoca-Manzanillo & 3 & 2 & 5 \\
Total & 99 & 41 & 140 \\
\hline
\end{tabular}


Appendix 4. Bivariate relationships between compliance and involvement in MPA decisions (A), type of MPA (B), being a fisher or not (C), effectiveness of government efforts against illegal fishing (D), tourism levels (E), MPA size (F), and support towards MPA (G). Values on Y-axis of panels A-G and X-axis of panels D-G are z-scores (see Methods section). Note that these figures do not show the marginal relationship between variables shown in Figure 1 (model output).

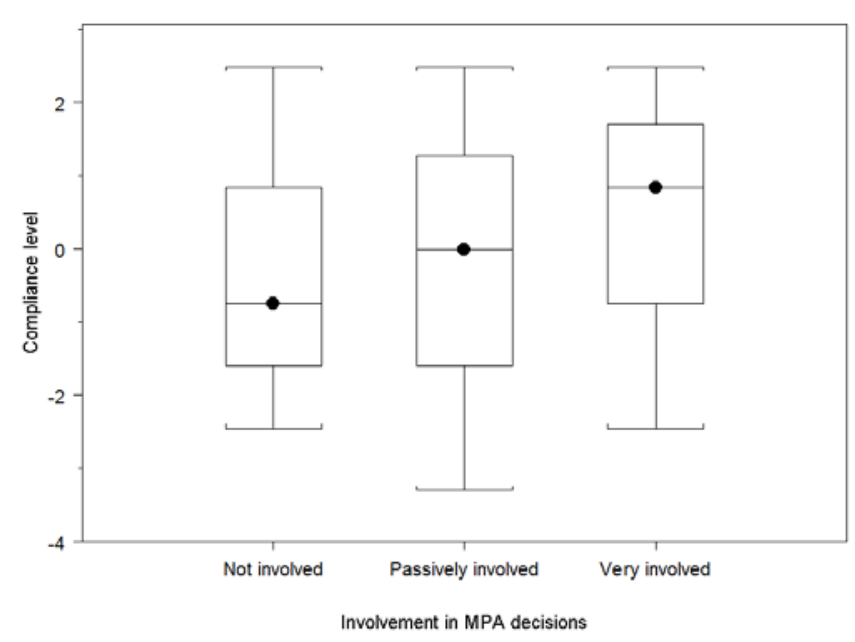

D

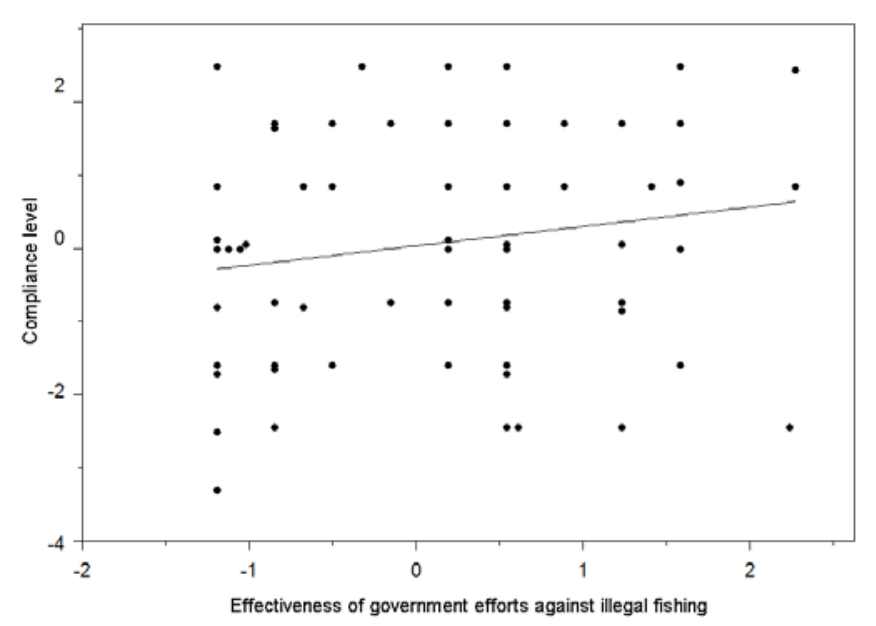

G

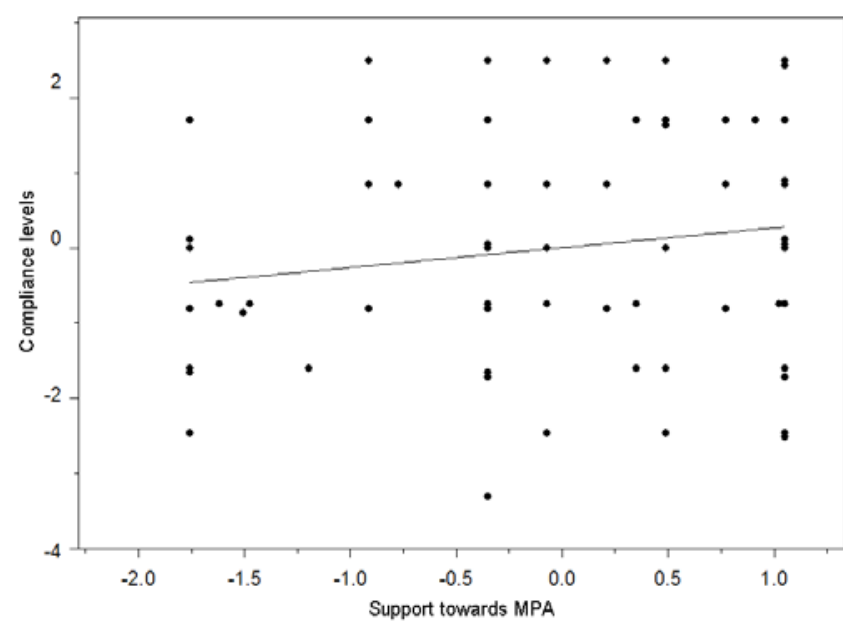

B

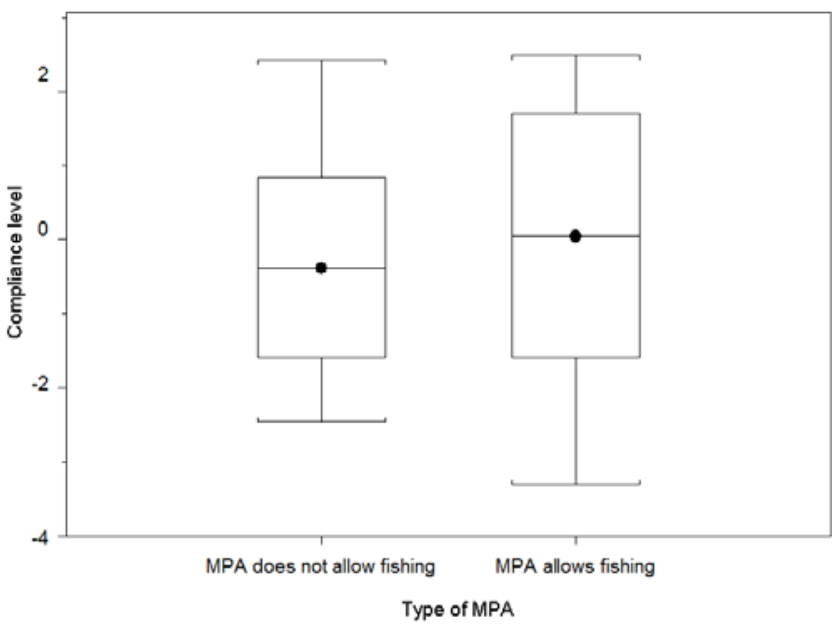

$\mathbf{E}$

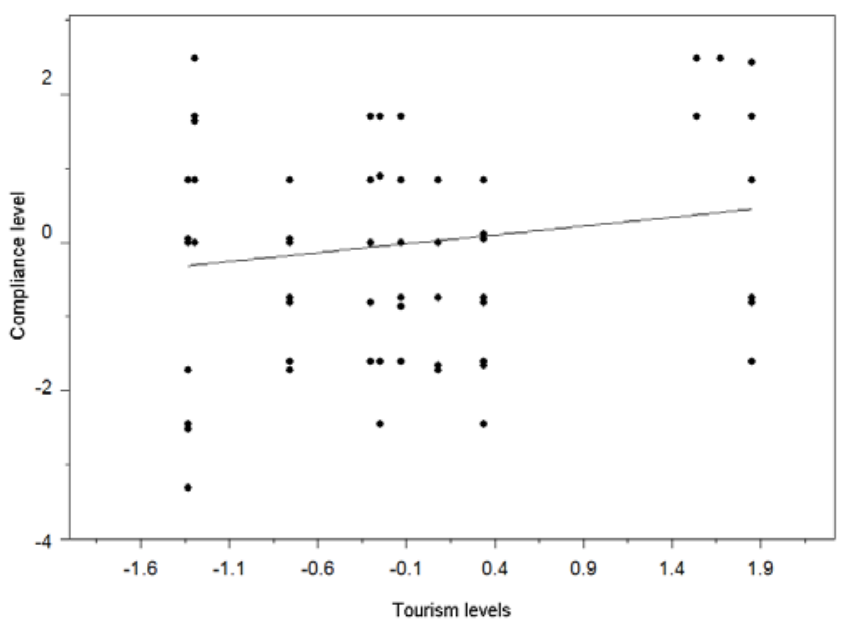

C

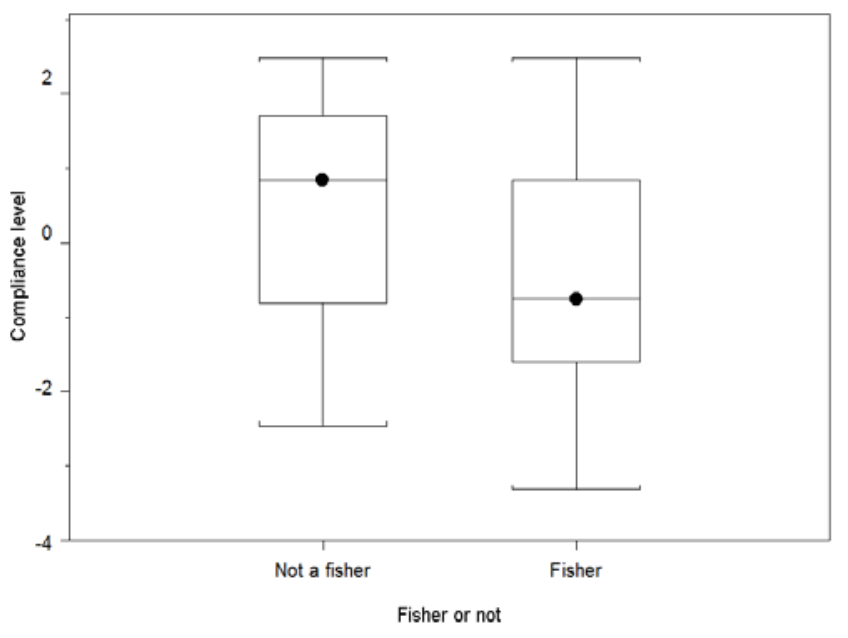

F

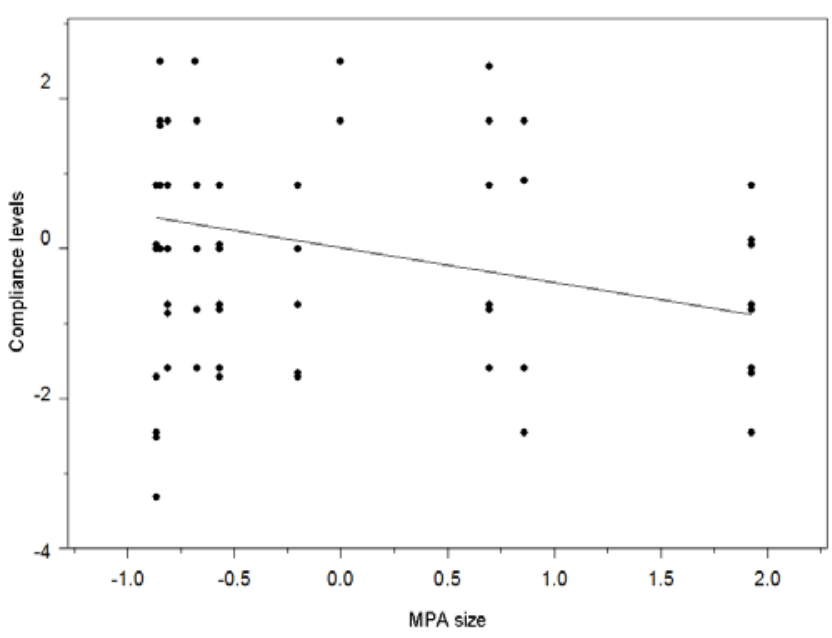

